Evaluation of Malathion, Diazinon,

A Silica Aerogel, and a Diatomaceous Earth

As Protectants on Wheat Against

Lesser Grain Borer Attack . . . in Small Bins

Marketing Research Report No. 860

Agricultural Research Service

UNITED STATES DEPARTMENT OF AGRICULTURE 


\section{Historic, archived document}

Do not assume content reflects current scientific knowledge, policies, or practices. 
This publication reports research involving pesticides. It does not contain recommendations for their use, nor does it imply that the uses discussed here have been registered. All uses of pesticides must be registered by appropriate State and/or Federal agencies before they can be recommended.

CAUTION: Pesticides can be injurious to humans, domestic animals, desirable plants, and fish or other wildlife - if they are not handled or applied properly. Use all pesticides selectively and carefully. Follow recommended practices for the disposal of surplus pesticides and pesticide containers.

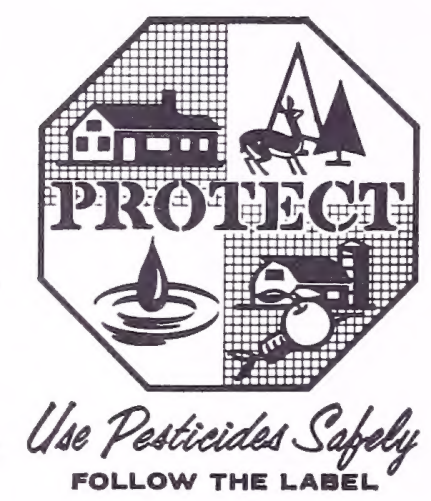

U.S. DEPARTMENT OF AGRICULTURE 


\section{PREFACE}

This report presents results of a small-bin, intermediate-type experiment with wheat treated with the standard malathion protectant application, a candidate chemically active insecticidal material (diazinon), a silica aerogel (Cab-O-Sil), and a diatomaceous earth (Kenite 2-I) for protection against the lesser grain borer. Materials and dosages treated were selected on the basis of previous laboratory and small-bin studies. The two experimental protectant materials_diazinon and Cab-O-Sil-have not been registered with the Pesticides Regulation Division, Agricultural Research Service, as grain storage treatments, and residue tolerances have not been established by the Food and Drug Administration for Cab-O-Sil or diazinon. All diatomaceous earth products containing more than 80 percent silicon dioxide are exempt from the requirements of a tolerance for use on certain stored grains including wheat.

Trade names or proprietary names are used in this publication solely to provide specific information. Mention of a trade name or testing of a material does not constitute a guarantee or warranty of the product by the U.S. Department of Agriculture and does not imply either a recommendation for its use or an endorsement over comparable products.

The entomological phases of the studies were conducted at the Mid-West Grain Insects Investigations Laboratory at Manhattan, Kans. Edwin Dicke, J. L. Wilson, Ralph L. Ernst, and Leon H. Hendricks assisted in the entomological phases. Residue determinations were made by A. G. Quintana, R. S. Cail, and M. Cooper of the Chemical Unit at the Stored-Product Insects Research and Development Laboratory, Savannah, Ga. Both laboratories are field stations of the Stored-Product Insects Research Branch, Market Quality Research Division, Agricultural Research Service, U.S. Department of Agriculture. 


\section{CONTENTS}

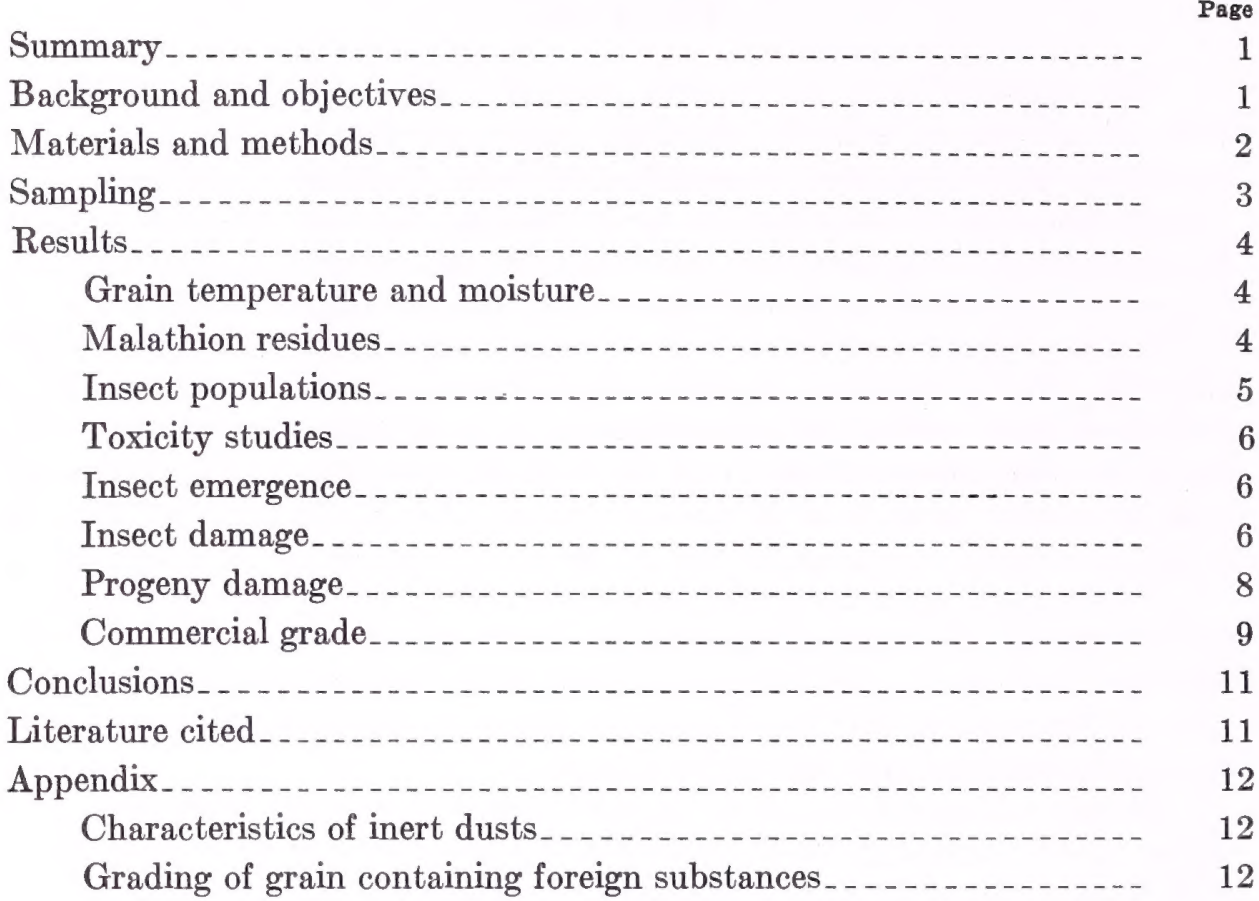




\title{
Evaluation of Malathion, Diazinon, a Silica Aerogel, and a Diatomaceous Earth as Protectants on Wheat Against Lesser Grain Borer Attack ... in Small Bins
}

\author{
By Delmon W. LA Hue, Entomologist \\ Market Quality Research Division, Agricultural Research Service
}

\section{SUMMARY}

Malathion, diazinon, and two inert dusts, a silica aerogel and a diatomaceous earth, were compared as protectants of wheat against the lesser grain borer in 5-cubic-foot bins for 12 months. The malathion residues degraded from 7.5 p.p.m. to 2.7 p.p.m. during this time.

Damaging infestations of lesser grain borers readily developed in all bins of the untreated check wheat from insects released in the storage room. Later in the storage period, although neither rice weevils nor flat grain beetles had been introduced by the experimenters, infestations of both these in- sects became established in the untreated wheat.

The silica aerogel Cab-O-Sil at 60 pounds per 1,000 bushels of wheat afforded nearly complete protection from insect damage for 12 months. The 1-pint dosage of malathion (0.63-pound active ingredient) and the 210-pound application of the diatomaceous earth Kenite $2-\mathrm{I}$ were only slightly less effective. Diazinon at a rate of 0.5 pint $(0.25$ pound active ingredient) per 1,000 bushels, protected the wheat from extensive damage for 6 months but its effectiveness diminished gradually thereafter.

\section{BACKGROUND AND OBJECTIVES}

Three phases of testing are required to develop a protective treatment for grain: First, a preliminary laboratory study to determine the toxicity and repellency of a test material to stored-product insects; second, an intermediate evaluation in small bins to compare promising materials at selected dosages with an accepted or standard insecticidal application and with untreated grain; and third, field-scale bin, warehouse, and elevator tests.

Only those materials most promising in the preliminary laboratory studies are further tested to evaluate dosage rates and effectiveness of residual protection. Five-cubic-foot cylindrical bins have been successfully used in extensive intermediatetype protectant studies with corn $(7),{ }^{1}$ farmers stock peanuts $(9)$, wheat $(6,10)$, and sorghum $(8)$.

Successful grain protectants are easy to apply, relatively safe to humans, effective in initial and residual action, and relatively low in cost. Only a very few materials that meet all of these criteria have been approved for use, but the search for new and promising residual protectant materials continues.

\footnotetext{
${ }^{1}$ Italic numbers in parentheses refer to items in "Literature Cited," p. 11.
}

Resistance of stored-product insects to insecticides and fumigants has been reported for many years from widespread areas, emphasizing the need for other acceptable insecticidal materials. Brown (1) reported that more than 150 cases of acquired insect resistance or tolerance to insecticides were known. However, relatively few of these were stored-product insects. Parkin and Forster (14) found that red flour beetles (Tribolium castaneum (Herbst) ) from a field-collected culture were far more difficult to kill with malathion than was a laboratory strain. Parker and Forster (13) and McDougall (11) reported that certain field-collected cultures of the rice weevil (Sitophilus oryzae (L.)) were more difficult to kill with lindane than laboratory-reared cultures. Numerous similar reports have been made. The probability of such field-acquired resistance or tolerance is of major importance. Laboratory-induced tolerance ratios do not indicate conditions in farm and commercial storages but do indicate what may happen under certain insecticidal selection pressures. The review of reports of resistance by Parkin (12) indicates the need to continue the search for new insecticides.

Strong et al. (18) stated that diazinon was more effective than malathion applied at equal dosages in acetone solutions to wheat against lesser grain 
borers (Rhyzopertha dominica (F.)), rice weevils, red flour beetles, confused flour beetles (Tribotium confusion Jacquelin duVal), Angoumois grain moths (Sitotroga cerealella (Olivier)), corn weevils (Sitophilus zeamais (Motschulsky)) and certain other stored-product insect pests. Malathion was more effective against saw-toothed grain beetles (Oryzaephitus surinamensis (L.)), merchant grain beetles ( $O$. mercator (Fauvel)) and granary weevils (Sitophitus granarius (L.)). Previous studies by Strong and Sbur $\left(16,1^{\text {r }}\right)$ had shown that diazinon was effective as a residual grain protectant.

Unpublished results from extensive laboratory studies by La Hue with four species of insects exposed to Hard Red Winter Wheat treated with diazinon as a water emulsion indicated that this chemical showed enough promise to warrant further investigation. Although diazinon is about 10 times more toxic to mammals than malathion, it seemed advisable to include it in a small-bin study to test protection of wheat against the lesser grain borer at a dosage less than that found effective by Strong. Milling and baking tests and flavor evaluations had indicated that the application of 8 parts per million (p.p.m.) of diazinon to common white wheats had no untoward effects on quality (19).

Two types of inert dust materials, namely, silica aerogels and diatomaceous earths, have shown some promise as grain protectants. Some work has been done with silica aerogels, and there has been considerable study of the diatomaceous earths. Cotton and Frankenfeld (2) reported that a silica aerogel was effective against stored-grain pests in wheat. King et al. (5) obtained satisfactory control of the rice weevil in grain sorghum with the silica aerogel SG-68.
In studies by Strong and Sbur (15), wheat seed treated with the diatomaceous earth Dicalite IG 3 showed no evidence of insect injury in comparison with the heavily damaged untreated check lots. Applications of 4, 6, and 8 pounds per ton appeared to be equally effective during the first 6 months after treatment. Only the 8-pound-per-ton application appeared to be effective against the lesser grain borer for longer than 9 months.

One pint of 57-percent malathion emulsifiable concentrate and 210 pounds of Kenite 2 -I per 1,000 bushels of wheat were about equally toxic to rice weevils and lesser grain borers exposed to samples periodically collected during a 15-month small-bin storage study (10). In the same study, 45 pounds of Cab-O-Sil per 1,000 bushels did not give satisfactory protection, although the results indicated that a higher dosage might be satisfactory. Flouryielding capacity and bread-baking properties of wheat were not changed by the addition of Cab-OSil or Kenite 2-I dusts. In another study, Cab-OSil was one of the five most promising dusts tested to prevent insect infestation (4) by direct application to dried fish.

The primary objective of this experiment was to compare the relative effectiveness of selected dosages of two basic types of chemically inert dusts and a candidate residual chemical to the standard malathion application, when applied to Hard Red Winter Wheat to prevent establishment of infestations after periodic introductions of active populations of the lesser grain borer. On the basis of promise shown in previous experiments, diazinon, Cab-O-Sil, and Kenite 2-I were selected for comparison with malathion in this intermediate-type, small-bin study.

The 1-year study started in 1966, and the first samplings were taken in February.

\section{MATERIALS AND METHODS}

Hard Red Winter Wheat was purchased locally at harvest and stored in bulk in a metal bin for 6 months. Immediately before treatment, the wheat was passed through a small shaker and fan-type seed cleaner to improve uniformity.

A malathion emulsion spray was prepared from premium-grade 57-percent malathion emulsifiable concentrate ( 5 pounds technical malathion per gallon) and neutral distilled water. It was applied at a dosage of 1 pint concentrate $(0.63$ pound active ingredient) per 1,000 bushels. This is the standard treatment for grain protection; it was included as a check for the other treatments.

A diazinon emulsion spray was formulated from a 48-percent diazinon emulsifiable concentrate (4 pounds technical diazinon per gallon) and neutral distilled water. The application rate was 0.5 pint of emulsifiable concentrate $(0.25$ pound active in- gredient) per 1,000 bushels.

Both emulsions were applied at the rate of 5 gallons of finished spray per 1,000 bushels with a DeVilbiss HM-521 compressed air spray gun through an aperture in the lid of a rotating barrel (fig. 1).

The silica aerogel Cab-O-Sil was applied at a rate of 60 pounds per 1,000 bushels and the diatomaceous earth Kenite 2-I at a 210-pound rate. All insecticidal materials were applied to 2 -bushel lots of wheat in the barrel, which rotated on its side at 16 revolutions per minute (r.p.m.) on an electric barrel roller for 5 minutes to mix the insecticide thoroughly with the wheat. Immediately after treatment of two lots, the 4 bushels of treated wheat were placed in a 5-cubic-foot bin (fig. 2).

Five bins of untreated wheat were included as checks. The grain surfaces were leveled to provide 


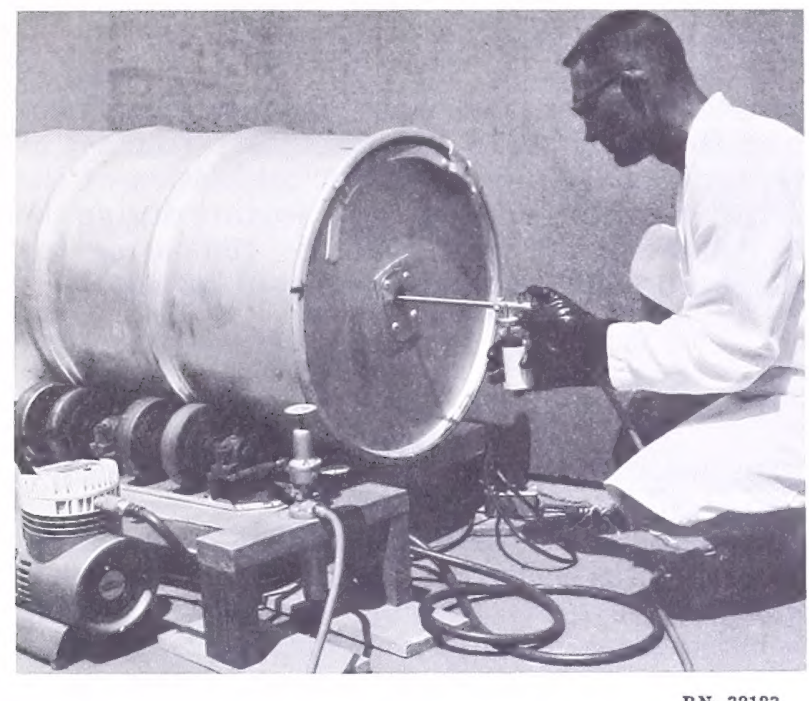

BN -32123

FIGURE 1.-Application of liquid insecticide to 2 bushels of grain through an aperture in the lid of a rotating barrel.

equal exposure areas in all bins. Each bin represented a treatment replicate, and all treatments were replicated 5 times in a 5 by 5 block selective randomized arrangement.

The 25 bins were placed in rows in a 13- by 18foot room. A humidistat-controlled water-evaporating cooling unit maintained a minimum relative humidity of about 50 percent. Conditions favored insect development throughout the storage period.

Major releases, each of about 5,000 vigorous lesser grain borer adults, were made in the storage room 10, 21, 42, 62, 126, and 198 days after the experiment was started. No flat grain beetles (Cryptolestes pusillus (Schönherr)) or rice wee-

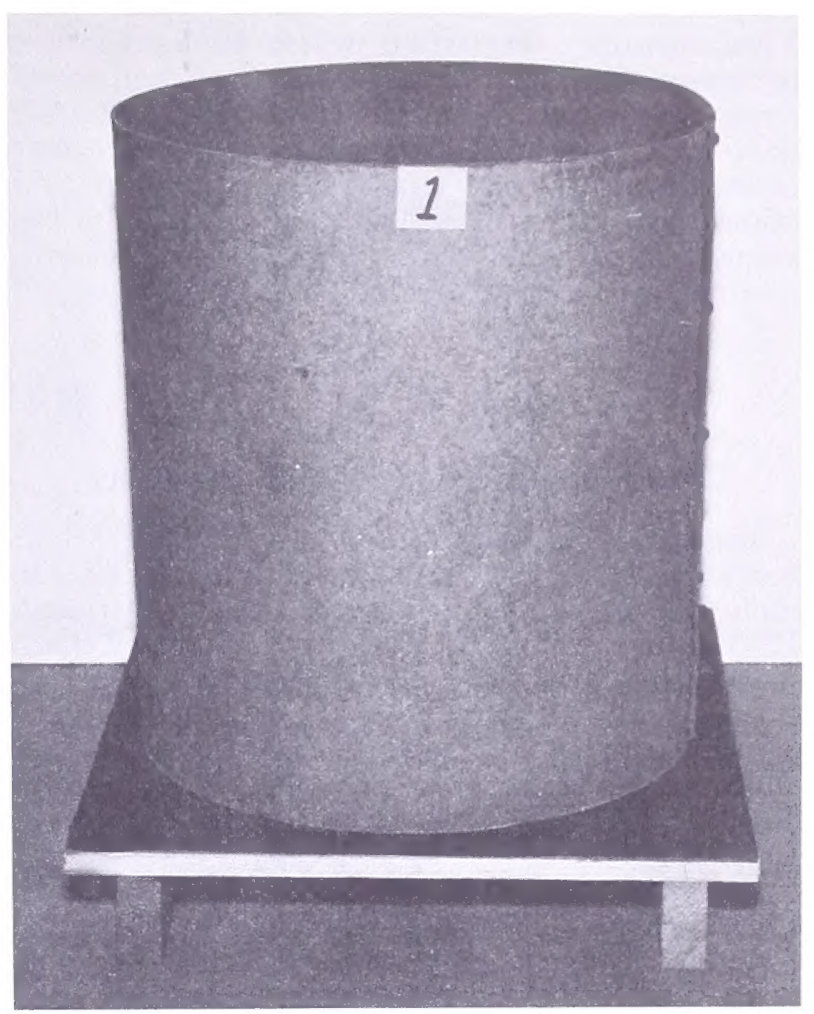

$\mathrm{BN}-31488$

Figure 2.-Cardboard drum, holding 4 bushels of grain, used as a small bin in testing insecticides as protectants of grain against insect attack.

vils were released in the room, but populations of both developed in the infestation room during the last 7 months of storage.

\section{SAMPLING}

Samples of grain were taken from the bins with a nonpartitioned grain trier 24 hours and 1, 3, 6, 9, and 12 months after treatment. The probe was inserted twice near the center of the bin and once about 2 inches from the bin wall in each of the four major directions. Soon after the samples were probed, they were shaken for 1 minute on a Rotomatic sifter to remove the insects. All fine dusts from the samples with the inert dust treatments were immediately separated from the screenings with a fine-mesh sieve and were returned to the parent sample for a 15-minute mixing period on a 33-r.p.m. wheel mixer. The live and dead insects were counted for an estimation of the populations in the various bins. The samples were sealed in 1-gallon glass jars until used for the periodic studies.

Replicated 200-gram subsamples from the probe samples were placed in 1-pint glass mason jars cov- ered with a 40 -mesh screen for the bioassay or toxicity tests. Adult lesser grain borers were exposed to the grain for 21 days at about $80^{\circ} \mathrm{F}$. and 60 percent relative humidity. After the toxicity tests were completed with mortality and progeny counts, all subsamples were retained for a later assessment of visible progeny damage.

The test weight, moisture content, and percent of damaged kernels were determined for each treatment. Samples from the malathion treatment were submitted for residue determination.

Immediately after treatment and again after 12 months' storage, commercial grades were determined. Information on the grading of grain containing foreign substances (3) is included in the appendix.

As each bin was emptied at the end of the 12month storage period, duplicate 1-gallon samples were progressively collected from top to bottom. 
These samples were sifted over a 10 -mesh screen to remove the insects, kernel bits, dusts, and insect frass. The screenings were sifted over a 20 -mesh sieve to separate the insect frass and other dusts from the insects and kernel bits. The frass and other dusts were weighed for an estimation of the amount of insect damage. The sifted wheat was retained in covered jars for 60 days for a record of insect emergence.

Before treatment and after $3,6,9$, and 12 months' storage, 1,000-kernel samples were examined from each bin to determine the percentage of kernels damaged by insects. A calculation of the kernel weight loss due to insect feeding during the 12-month storage was made by comparing the weights of damaged and undảmaged kernels.

\section{RESULTS}

\section{Grain Temperature and Moisture}

Temperatures were taken with mercury thermometers from near the center of the grain mass in each bin at weekly intervals after treatment. Higher temperatures in the bins of untreated check wheat were first noted during the fifth month of storage and continued through the rest of the 12 months (table 1). During the last 3 months, the temperatures in the untreated bins were about $30^{\circ}$ higher than in the bins containing treated wheat. Higher temperatures were noted in some of the bins containing diazinon-treated wheat 9 months after treatment; however, some bins with the diazinon treatment did not have higher temperatures caused by insects even after 12 months' storage. No higher temperatures due to insect activity were recorded in the bins with the malathion, Cab-O-Sil, or Kenite 2-I treatments.

Changes in the moisture content of the grain paralleled the changes in grain temperature. They increased slightly during the warm spring months; thereafter a gradual decline was noted in all bins except the untreated checks (table 2).

\section{Malathion Residues}

Data from the residue analyses (table 3) are expressed in parts per million (p.p.m.) of the insecticide, based on the actual weight of the wheat. The residues recovered immediately after treatment ranged from 6.2 to 8.4 p.p.m. and averaged 7.5 p.p.m. In samples taken 1 month later, an average of 9.1 p.p.m. malathion was recorded. In sub-

TABLE 1.-Average grain mass temperatures during 12 months' storage

\begin{tabular}{|c|c|c|c|c|c|c|c|c|c|c|c|c|}
\hline \multirow{2}{*}{$\begin{array}{c}\text { Insecticide and dosage per } 1,000 \\
\text { bushels }\end{array}$} & \multicolumn{12}{|c|}{ Months of storage } \\
\hline & 1 & 2 & 3 & 4 & 5 & 6 & 7 & 8 & 9 & 10 & 11 & 12 \\
\hline Malathion 1 nint & ${ }^{\circ} \mathrm{F}$ & ${ }^{\circ} \mathrm{F}$ & ${ }^{\circ} \mathrm{F}$ & ${ }^{\circ} \mathrm{F}$ & ${ }^{\circ} \mathrm{F}$ & ${ }^{\circ} \mathrm{F}$ & ${ }^{\circ} \mathrm{F}$ & ${ }^{\circ} \mathrm{F}$. & ${ }^{\circ} \mathrm{F}$. & ${ }^{\circ} \mathrm{F}$. & ${ }^{\circ} \mathrm{F}$. & ${ }^{\circ} \mathrm{F}$. \\
\hline Diazinon, 0.5 pint & $\begin{array}{l}04.0 \\
64.3\end{array}$ & 70.1 & 73.6 & 76. 6 & $\begin{array}{l}\text { 84. } 0 \\
84.0\end{array}$ & $\begin{array}{l}81 . \\
80.7\end{array}$ & $\begin{array}{l}70.5 \\
76.3\end{array}$ & 72.4 & 69. 7 & 67. 1 & 68. 5 & 72.7 \\
\hline Cab-O-Sil, 60 pounds & 64. 6 & 70.6 & 73. 8 & 76. 7 & 84. 0 & 81.1 & 76. 4 & 72. 2 & 69.0 & 65.9 & 66. 9 & 67. 1 \\
\hline Kenite $2-\mathrm{I}, 210$ pounds..... & 64.5 & 70.4 & 73. 7 & 77. 0 & 84.1 & 81. 0 & 76. 7 & 72. 6 & 69.4 & 66.4 & 66. 9 & 67.5 \\
\hline Untreated check & 64. 7 & 70. 2 & 73. 7 & 77. 2 & 91.0 & 97.9 & 85.2 & 81.8 & 83.9 & 98.3 & 99. 3 & 100.5 \\
\hline
\end{tabular}

TABLE 2.-Moisture content of Hard Red Winter Wheat at given intervals after insecticide treatment

\begin{tabular}{|c|c|c|c|c|c|c|c|}
\hline \multirow{2}{*}{$\begin{array}{c}\text { Insecticide and dosage per } 1,000 \\
\text { bushels }\end{array}$} & \multicolumn{7}{|c|}{ Moisture content ${ }^{1}$} \\
\hline & $\begin{array}{c}\text { Before } \\
\text { treatment }\end{array}$ & $\begin{array}{c}\text { Immediately } \\
\text { after } \\
\text { treatment }\end{array}$ & $\begin{array}{l}\text { After } \\
1 \\
\text { month }\end{array}$ & $\begin{array}{c}\text { After } \\
3 \\
\text { months }\end{array}$ & $\begin{array}{c}\text { After } \\
6 \\
\text { months }\end{array}$ & $\begin{array}{c}\text { After } \\
9 \\
\text { months }\end{array}$ & $\begin{array}{c}\text { After } \\
12 \\
\text { months }\end{array}$ \\
\hline Sprays: & Percent & Percent & Percent & Percent & Percent & Percent & Percent \\
\hline Malathion, 1 pint & 11. 79 & 11.84 & 11. 70 & 12. 16 & 11. 89 & 11. 30 & 11. 28 \\
\hline Diazinon, 0.5 pint & 11. 72 & 11. 83 & 11. 70 & 12. 20 & 11. 86 & 11. 19 & 11.14 \\
\hline Dusts: & & & & & & & \\
\hline $\begin{array}{l}\text { Cab-O-Sil, } 60 \text { pounds } \\
\text { Kenite } 2-\mathrm{I}, 210 \text { pounds. }\end{array}$ & $\begin{array}{l}\text { 11. } 69 \\
\text { 11. } 79\end{array}$ & $\begin{array}{l}11.53 \\
11.63\end{array}$ & $\begin{array}{l}11.46 \\
11.54\end{array}$ & $\begin{array}{l}11.84 \\
11.95\end{array}$ & $\begin{array}{l}11.58 \\
11.58\end{array}$ & $\begin{array}{l}10.88 \\
10.89\end{array}$ & $\begin{array}{l}10.83 \\
10.86\end{array}$ \\
\hline Untreated check & 11. 74 & 11. 73 & 11. 68 & 12. 16 & 11. 28 & 11. 69 & 12.06 \\
\hline
\end{tabular}

${ }^{1}$ Determined on a RC 512 Steinlite Moisture Tester. 


\section{TABLE 3.-Malathion residues on Hard Red Winter Wheat at given intervals during storage 1}

\begin{tabular}{|c|c|c|c|c|c|c|}
\hline $\begin{array}{l}\text { Replication } \\
\text { number }\end{array}$ & $\begin{array}{c}\text { Immediately } \\
\text { after } \\
\text { treatment }\end{array}$ & $\begin{array}{c}\text { After } \\
1 \\
\text { month }\end{array}$ & $\begin{array}{c}\text { After } \\
3 \\
\text { months }\end{array}$ & $\begin{array}{c}\text { After } \\
6 \\
\text { months }\end{array}$ & $\begin{array}{c}\text { After } \\
9 \\
\text { months }\end{array}$ & $\begin{array}{c}\text { After } \\
12 \\
\text { months }\end{array}$ \\
\hline $\begin{array}{l}\text { 1 } 2 \ldots \\
2 \\
3 \\
4 \\
4 \\
5\end{array}$ & $\begin{array}{r}\text { P.p.m. } \\
8.3 \\
8.0 \\
8.4 \\
6.2 \\
6.6 \\
7.5\end{array}$ & $\begin{array}{r}\text { P.p.m. } \\
7.8 \\
9.0 \\
8.6 \\
8.8 \\
11.5 \\
9.1\end{array}$ & $\begin{array}{r}\text { P.p.m. } \\
\text { 7. } 6 \\
5.4 \\
8.7 \\
\text { 3. } 8 \\
5.9 \\
6.3\end{array}$ & $\begin{array}{r}\text { P.p.m. } \\
2.8 \\
4.1 \\
4.0 \\
3.0 \\
3.7 \\
3.5\end{array}$ & $\begin{array}{r}\text { P.p.m. } \\
2.7 \\
3.9 \\
2.8 \\
2.5 \\
3.4 \\
3.1\end{array}$ & $\begin{array}{l}\text { P.p.m. } \\
\begin{aligned} 2.4 \\
2.8 \\
3.0 \\
2.8 \\
2.7 \\
2.7\end{aligned}\end{array}$ \\
\hline
\end{tabular}

1 Values are expressed in parts per million of the insecticide based on actual weight of the wheat.

sequent determinations, the malathion residues gradually decreased.

Analyses were not made to determine the diazinon residues.

\section{Insect Populations}

The numbers of live adult insecis recovered from probe samples taken from all bins in the infestation room at intervals indicated the populations within the bins (tables 4 and 5). After 1 month of storage, small infestations of lesser grain borers were already established in the untreated check wheat. The progeny developing in probings from these bins produced a considerable amount of damage to the grain (table 11). After 3 months, lesser grain borer populations in the untreated grain had increased nearly sixfold, and after 6 months, tremendous numbers of lesser grain borers were found. Although all of the treatments of the wheat showed excellent control of these insects at 6 months, fewer insects were found in bins treated with Cab-O-Sil and Kenite 2-I than in bins treated with either malathion or diazinon. Progeny damage tests (table 11) showed that only mala- thion protected the wheat for 6 months from becoming infested; however, very little progeny damage occurred in wheat treated with Kenite 2-I and Cab-O-Sil.

After 9 months' storage, it was evident that the effectiveness of the diazinon was diminishing. Comparatively few lesser grain borers were found at that time in the wheat treated with either dust, and slightly larger populations in the wheat treated with malathion. Only malathion, however, effectively prevented damage by progeny (table 11). Similar results were recorded during the 12 months' examinations. Very little differences were found between the results of the malathion, Cab-OSil, and Kenite 2-I treatments.

The inert dust treatments protected the wheat from nonintroduced "wild" insects for 12 months. Malathion and diazionon failed to protect against the rice weevil at 9 and 12 months. By the end of 6 months, an infestation of flat grain beetles had become established in the untreated check bins. This infestation increased to damaging proportions by the end of 12 months. A considerable infestation of other insects was present in the same bins. Very few rice weevils were present in the untreated grain.

TABLE 4.-Lesser grain borer adults in probe samples taken during 12 months' storage

\begin{tabular}{|c|c|c|c|c|c|}
\hline \multirow{2}{*}{$\begin{array}{l}\text { Insecticide and dosage per } \\
1,000 \text { bushels }\end{array}$} & \multicolumn{5}{|c|}{ Insects in samples taken after- } \\
\hline & 1 month & 3 months & 6 months & 9 months & 12 months \\
\hline Sprays: & Number & Number & Number & Number & Number \\
\hline Malathion, 1 pint $\ldots \ldots$ & 3 & 18 & 105 & 79 & 130 \\
\hline Diazinon, 0.5 pint & 7 & 90 & 114 & 913 & 1,653 \\
\hline \multicolumn{6}{|l|}{ Dusts: } \\
\hline Cab-O-Sil, 60 pounds _... & 3 & 12 & 2 & 25 & 15 \\
\hline Kenite $2-\mathrm{I}, 210$ pounds & 4 & 38 & 31 & 36 & 44 \\
\hline Untreated check & 100 & 574 & 9,060 & 15,247 & 18,604 \\
\hline
\end{tabular}




\section{Toxicity Studies}

Bioassay tests were conducted with lesser grain borers exposed in replicate to subsamples of wheat from the different treatments.

Malathion was effective against the lesser grain borer in toxicity tests conducted during the first 3 months of storage; but thereafter, its efficiency against adult borers gradually diminished and progeny damage was quite evident (tables 6 and 12). Diazinon was less effective than malathion. Cab-O-Sil and Kenite 2-I both suppressed progeny development of the lesser grain borer throughout the entire storage period but at no time completely controlled the adults nor prevented progeny damage.

\section{Insect Emergence}

The emergence of insects from the 1-gallon samples of wheat taken progressively as the bins were emptied at the end of the test indicated the extent of the selft-contained infestations that had become established in the wheat. Fewer insects emerged from the untreated wheat than might have been expected from its heavily damaged condition. CabO-Sil prevented the establishment of rice weevil, flour beetle, or flat grain beetle infestations, but a few lesser grain borers did emerge (table 7). No flour beetles or flat grain beetles emerged from wheat treated with malathion, but rice weevil infestations were firmly established. Fewer lesser grain borers emerged from malathion-treated wheat than from any other treatment. Relatively large numbers of lesser grain borers emerged from the Kenite 2-I treated wheat. Both rice weevils and lesser grain borers infested the diazinontreated wheat.

\section{Insect Damage}

Insects may inflict a certain amount of damage before they are killed by insecticide residues. Damage to the inside of kernels results in weight losses. Heavily damaged kernels may break into fragments during handling. Insect damage to the wheat can be expressed in percent of kernels damaged by insects, kernel weight losses, losses in pounds per bushel, amount of insect frass, and ratings of visible damage by insect progeny.

Very little weight loss was due to damage by the several species of insects present during the 12 months in wheat treated with Kenite 2-I or Cab-O-Sil (table 8). Wheat treated with malathion and diazinon lost 0.8 and 1.6 pounds per bushel, respectively. Untreated wheat lost about 14.7 pounds per bushel, or 24 percent of its original weight, to insects during 12 months of storage.

The percent of insect-damaged kernels was determined from 1,000-kernel samples from each bin, and weight losses were calculated from this figure.

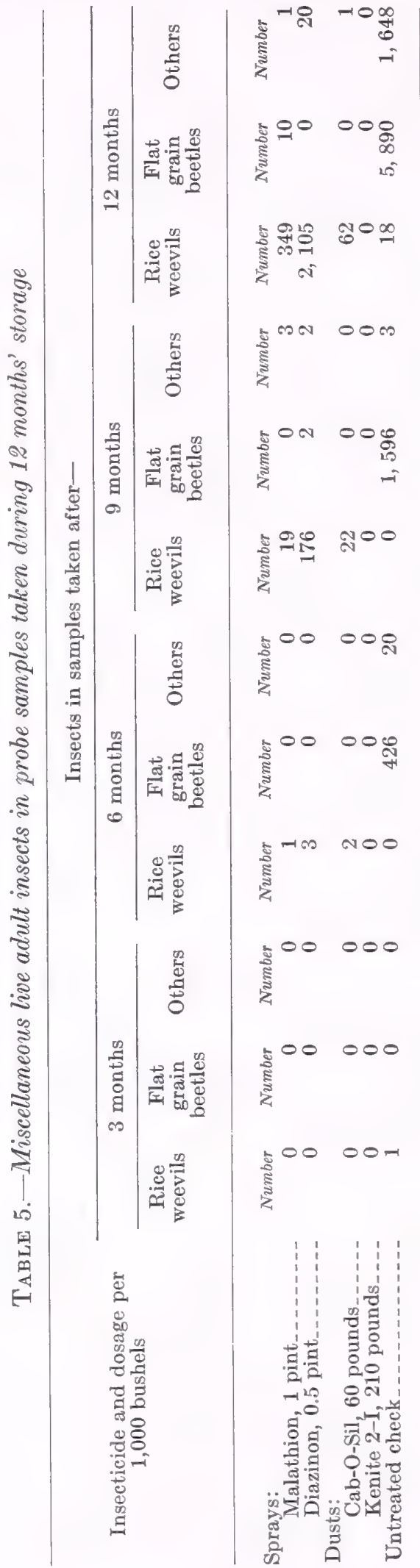




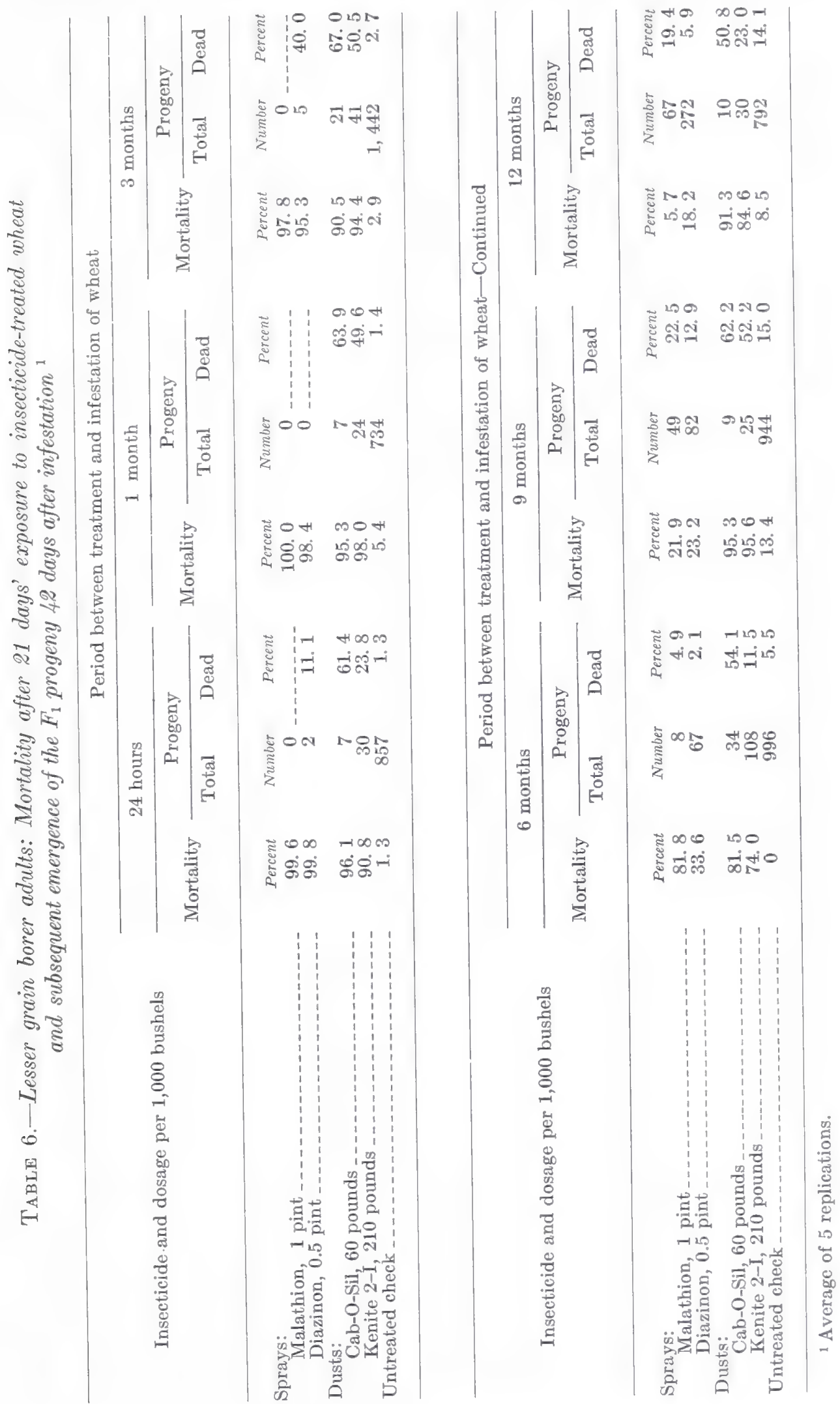


About 1.40 percent of tho kernels showed insect damage before treatment. Only a 0.19 -percent loss in kernel weight was calculated for wheat from the Cab-O-Sil treatment during 12 months' storage (table 9). Kernel weight losses of 0.60 and 1.13 percent were calculated for wheat treated with Kenite 2-I and malathion, respectively. The increase from 1.38 to 11.72 percent of kernels damaged by insects in wheat treated with diazinon resulted in a kernel weight loss calculated at only 2.38 percent. The calculated kernel weight loss in the untreated wheat was 34.07 percent, with 73.84 percent of the kernels damaged after 12 months' storage.

The calculated kernel weight losses of $0.19,0.60$, and 1.13 percent for Cab-O-Sil, Kenite $2-\mathbf{I}$, and malathion treatments, respectively, confirm the small recorded losses in test weight due to insect damage.

Weights of fine dust, primarily insect frass, sifted from samples taken as the bins were emptied during the termination of the test, indicated the damage from insect feeding during storage. The small amounts of dust recovered from the bins treated with Cab-O-Sil and malathion reflected the slight amount of damage to the wheat with these treatments (table 10). The amounts of dust recovered from the Kenite 2-I treatment were larger than expected, although part of this was undoubtedly dust originally applied. The large amount of dust recovered from the untreated grain reflected the great amount of insect damage.

\section{Progeny Damage}

Remnant samples from the periodic probings and test subsamples were held for 4 or 5 months to observe the extent of the damage by progeny of established infestations.

A study of the damage in samples from the periodic probings indicates that malathion gave the best overall protection during the first 9 months (table 11). Damage to wheat treated with Cab-OSil and Kenite 2-I was not great, but infestations in the wheat treated with diazinon had caused considerable damage after 3 months' storage.

Damage to the samples from toxicity tests indicated that lesser grain borers, although some-

TABLE 7.-Emergence of insects from 1-gallon samples of wheat taken at end of the experiment

\begin{tabular}{|c|c|c|c|c|c|c|}
\hline $\begin{array}{c}\text { Insecticide and dosage } \\
\text { per } 1,000 \\
\text { bushels }\end{array}$ & $\begin{array}{c}\text { Rice } \\
\text { weevils }\end{array}$ & $\begin{array}{c}\text { Flour } \\
\text { beetles }\end{array}$ & $\begin{array}{l}\text { Flat } \\
\text { grain } \\
\text { beetles }\end{array}$ & $\begin{array}{l}\text { Lesser } \\
\text { grain } \\
\text { borers }\end{array}$ & Others & Total \\
\hline Sprays: & Number & Number & Number & Number & Number & Number \\
\hline Malathion, 1 pint & 233 & 0 & 0 & 18 & 0 & 251 \\
\hline Diazinon, 0.5 pint & 400 & 1 & 1 & 606 & 0 & 1,008 \\
\hline Dusts: & & & & & & \\
\hline Cab-()-Sil, 60 pounds_._-_. & 0 & 0 & 0 & 33 & 0 & $\begin{array}{r}33 \\
845\end{array}$ \\
\hline Kenite 2-I, 210 pounds & 0 & 0 & $\begin{array}{r}0 \\
168\end{array}$ & 845 & 0 & 845 \\
\hline Untreated check & 2 & 46 & 168 & 1,869 & 0 & 2,085 \\
\hline
\end{tabular}

TABLE 8.-Weight loss per bushel of insecticide-treated Hard Red Winter Wheat at given intervals during storage

Insecticide and dosage per 1,000 bushels
Weight per bushel-

\begin{tabular}{|c|c|c|c|c|c|c|}
\hline $\begin{array}{c}\text { Immediately } \\
\text { after } \\
\text { treatment }\end{array}$ & $\begin{array}{l}\text { After } 1 \\
\text { month }\end{array}$ & $\begin{array}{l}\text { After } 3 \\
\text { months }\end{array}$ & $\begin{array}{l}\text { After } 6 \\
\text { months }\end{array}$ & $\begin{array}{l}\text { After } 9 \\
\text { months }\end{array}$ & $\begin{array}{c}\text { After } 12 \\
\text { months }\end{array}$ & Loss \\
\hline $\begin{array}{l}\text { Pounds } \\
60.2 \\
60.4\end{array}$ & $\begin{array}{l}\text { Pounds } \\
\quad 60.5 \\
\quad 60.5\end{array}$ & $\begin{array}{l}\text { Pounds } \\
\quad 60.5 \\
\quad 60.6\end{array}$ & $\begin{array}{l}\text { Pounds } \\
\quad 60.4 \\
\quad 60.6\end{array}$ & $\begin{array}{l}\text { Pounds } \\
59.9 \\
59.8\end{array}$ & $\begin{array}{l}\text { Pounds } \\
59.4 \\
58.7\end{array}$ & $\begin{array}{l}\text { Pounds } \\
\quad 0.8 \\
1.7\end{array}$ \\
\hline $\begin{array}{l}54.5 \\
55.3 \\
60.3\end{array}$ & $\begin{array}{l}54.6 \\
55.3 \\
60.5\end{array}$ & $\begin{array}{l}54.5 \\
55.2 \\
60.2\end{array}$ & $\begin{array}{l}54.3 \\
55.0 \\
52.7\end{array}$ & $\begin{array}{l}\text { 54. } 6 \\
55.2 \\
46.4\end{array}$ & $\begin{array}{l}54.4 \\
55.0 \\
45.6\end{array}$ & $\begin{array}{r}1 \\
14.7 \\
14\end{array}$ \\
\hline
\end{tabular}

60. 3

60.5
60,2
55. 4

45. 6

14. 7
Sprays:

Malathion, 1 pint $\ldots \ldots \ldots \ldots$

Dusts:

Diazinon, 0.5 pint

Cab-O-Sil, 60 pounds_.........

Kenite 2-I, 210 pounds.......

Untreated check $\ldots$ 
TABLE 9.-Kernel damage by insects in insecticide-treated Hard Red Winter Wheat during 12 months' storage

\begin{tabular}{|c|c|c|c|c|c|c|}
\hline \multirow{2}{*}{$\begin{array}{c}\text { Insecticide and dosage per } 1,000 \\
\text { bushels }\end{array}$} & \multicolumn{5}{|c|}{ Kernels damaged in sample- } & \multirow{2}{*}{$\begin{array}{l}\text { Calculated } \\
\text { weight } \\
\text { loss }\end{array}$} \\
\hline & $\begin{array}{l}\text { Before } \\
\text { treatment }\end{array}$ & $\begin{array}{l}\text { After } \\
3 \\
\text { months }\end{array}$ & $\begin{array}{l}\text { After } \\
6 \\
\text { months }\end{array}$ & $\begin{array}{l}\text { After } \\
9 \\
\text { months }\end{array}$ & $\begin{array}{l}\text { After } \\
12 \\
\text { months }\end{array}$ & \\
\hline $\begin{array}{l}\text { Sprays: } \\
\text { Malathion, } 1 \text { pint } \\
\text { Diazinon, } 0.5 \text { pint }\end{array}$ & $\begin{array}{r}\text { Percent } \\
\text { 1. } 40 \\
1.38\end{array}$ & $\begin{array}{r}\text { Percent } \\
\text { 1. } 48 \\
\text { 1. } 58\end{array}$ & $\begin{array}{l}\text { Percent } \\
1.70 \\
1.86\end{array}$ & $\begin{array}{r}\text { Percent } \\
\text { 3. } 60 \\
5.74\end{array}$ & $\begin{array}{r}\text { Percent } \\
4.08 \\
11.72\end{array}$ & $\begin{array}{r}\text { Percent } \\
1.13 \\
\text { 2. } 38\end{array}$ \\
\hline $\begin{array}{l}\text { Dusts: } \\
\text { Cab-O-Sil, } 60 \text { pounds } \\
\quad \text { Kenite } 2-1,210 \text { pounds. } \\
\text { Untreated check }\end{array}$ & $\begin{array}{l}\text { 1. } 62 \\
\text { 1. } 36 \\
\text { 1. } 30\end{array}$ & $\begin{array}{r}1.44 \\
1.34 \\
21.52\end{array}$ & $\begin{array}{r}1.52 \\
\text { 1. } 48 \\
41.78\end{array}$ & $\begin{array}{r}2.32 \\
\text { 1. } 92 \\
67.76\end{array}$ & $\begin{array}{r}\text { 2. } 40 \\
\text { 3. } 86 \\
\text { 73. } 84\end{array}$ & $\begin{array}{r}.19 \\
34.60 \\
34.07\end{array}$ \\
\hline
\end{tabular}

what suppressed, could become established in wheat protected by Cab-O-Sil and Kenite 2-I (ta-

TABLE 10.-Weight of fine dust and insect frass from insecticide-treated wheat samples collected as the bins were emptied

\begin{tabular}{|c|c|c|}
\hline \multirow{2}{*}{$\begin{array}{l}\text { Insecticide and dosage per } \\
1,000 \text { bushels }\end{array}$} & \multicolumn{2}{|c|}{ Dust and frass weight ${ }^{1}$} \\
\hline & Average $^{2}$ & Range \\
\hline Sprays: & Grams & Grams \\
\hline Malathion, 1 pint...... & 1. 84 & 1. $2-1.7$ \\
\hline Diazinon, 0.5 pint $\ldots . .$. & 5.45 & 1. $9-10$. \\
\hline Dusts: & & \\
\hline $\begin{array}{l}\text { Cab-O-Sil, } 60 \text { pounds }- \\
\text { Kenite } 2-\mathrm{I}, 210 \text { pounds }\end{array}$ & 1. 48 & $.8-3.8$ \\
\hline $\begin{array}{l}\text { Kenite } 2-1,210 \\
\text { Untreated check }\end{array}$ & 383.13 & $\begin{array}{l}\text { 3. } 3-0.3 \\
\text { 318. } 0-503.5\end{array}$ \\
\hline
\end{tabular}

${ }^{1}$ Per 1-gallon sample.

22 samples per bin; 5 bins of each treatment. ble 12). Malathion protected completely during the first part of the storage, but after 6 months infestations established during toxicity tests did some damage.

\section{Commercial Grade}

At the beginning of the experiment, a composite taken from all grain being used for the different treatments, and composites from each treatment were submitted for official grade determinations. After 1 year's storage, treatment composites were again graded and compared with untreated wheat (table 13).

The source untreated wheat graded No. 1 Hard Winter. Treatment with Kenite 2-I reduced the test weight 4.3 pounds per bushel and with $\mathrm{Cab}-\mathrm{O}$ Sil 5.5 pounds. After 12 months' storage, the test weights of wheat from these two treatments had not materially changed. Lowered test weight was

TABLE 11.-Visible damage by insect progeny in composited bin samples taken during 12 months' storage

Insecticide and dosage per 1,000 bushels

Damage observed 150 days after sampling following storage periods of ${ }^{2}-$

24 hours 1 month 3 months 6 months 9 months 12 months

Sprays:

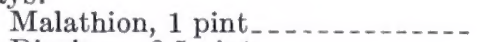

Dusts:

Diazinon, 0.5 pint_...

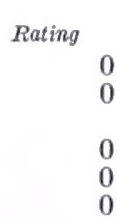

$\begin{aligned} & \text { Rating } \\ & 0 \\ & 0 \\ & \\ & \\ & 0 \\ & 0 \\ & \\ & 2.8\end{aligned}$

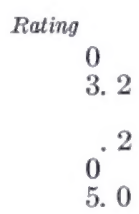

Rating
0
4. 0

.6
5.6
5. 0

Rating
0. 2
4. 0

1. 0
1. 0
4. 2

Rating

0. 2

3. 0

Cab-O-Sil, 60 pounds

Untreated check 210 pounds........

2. 8

5. 6

1. 0

4. 2

4. 0

$\cdot 6$

2. 0

${ }^{1}$ Damage ratings code: $0=$ no visible infestation; $1=$ slight damage as evidenced by a few insects and a small amount of insect frass; 2,3 , and $4=$ ascending numbers of insects and corresponding amount of insect frass ; $5=$ large infestation with great amounts of insect frass and spoilage of grain. 
the predominant factor responsible for the low numerical grade of wheat treated with these dusts. Wheat treated with diazinon and Cab-O-Sil was graded DLQ (distinctly low quality) because of the presence of an unknown substance. ${ }^{2}$

${ }^{2}$ See "Grading of Grain Containing Foreign Substances" in the appendix.
Total defects in wheat treated with malathion and with Cab-O-Sil increased slightly from 1.3 to 1.8 and from 0.7 to 1.2 percent, respectively, during the 12-month storage. Defects in the wheat treated with Kenite 2-I increased from 1.1 to 2.8 percent. Total defects in diazinon-treated wheat increased from 1.5 to 5.7 percent, but the increase was from 1.6 to 61.2 percent in the untreated wheat.

TABLE 12.-Visible damage by lesser grain borer progeny in composited samples from the toxicity tests

Insecticide and dosage per 1,000 bushels

Sprays:

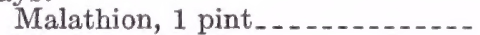

Diazinon, 0.5 pint

Dusts:

Cab-O-Sil, 60 pounds.

Kenite 2-I, 210 pounds......Untreated check.
Damage observed 120 days after sampling following storage periods of 1 -

\begin{tabular}{|c|c|c|c|c|c|}
\hline 24 hours & 1 month & 3 months & 6 months & 9 months ${ }^{2}$ & 12 months ${ }^{2}$ \\
\hline Rating & Rating & Rating & Rating & Rating & Rating \\
\hline 0 & 0 & 0 & 1. 2 & 1. 2 & 1. 2 \\
\hline 0 & 1 & .6 & 3. 2 & 3. 0 & 3.8 \\
\hline .2 & 1 & .4 & 1. 4 & 1. 0 & .8 \\
\hline 2.0 & 2 & 1. 2 & 3.0 & 1. 4 & 1. 4 \\
\hline 35.0 & 35 & 5. 0 & 5. 0 & 4. 6 & 4. 0 \\
\hline
\end{tabular}

1 Damage ratings code: $0=$ no visible infestation; $1=$ slight damage as evidenced by a few insects and a small amount of insect frass; 2,3 , and $4=$ ascending numbers of insects and corresponding amount of insect frass;
$5=$ large infestation with great amounts of insect frass and spoilage of grain.

2 Damage assessment made 90 days after infestation.

${ }^{3}$ Grade 5 after 90 days.

\section{TABLE 13.-Commercial grade factors determined on the grain before and after treatment and after 12 months' storage}

Insecticide treatment and grading interval
Grade factors

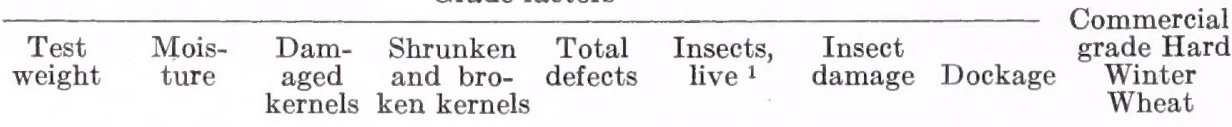

Untreated:

Check:

Source composite. After 12 months ..

$\begin{array}{rrr}\text { Pounds } & \text { Percent } & \text { Percent } \\ 60.0 & 11.5 & 0.8 \\ 43.2 & 13.5 & 60.0\end{array}$

$\begin{array}{rr}\text { Percent } & \text { Percent } \\ 0.8 & 1.6 \\ 1.1 & 61.2\end{array}$

Number
0
20

Percent
0.2
56.0

Percent

0.02

.30

1. 3

$\begin{array}{ll}.8 & 1.3 \\ .7 & 1.8 \\ .7 & 1.5 \\ .7 & 5.7\end{array}$

1. 5

12. 0

60.5
59.8

12. 0

60. 5

11. 7

After 12 months.--

58. 5

12. 4

5. 8

1. 5

7
.6

.0

54. 5

10. 9

After treatment...

After 12 months...

Kenite 2-1:

After treatment...

After 12 months

55. 0

11. 2

. 6

.7

55. $7 \quad 11.0$

55. 2 11. 5 i. 2

1. 1
2. 0

6
.8

2. 8

${ }^{2} \mathrm{DLQ}$ - Presence of unknown substance. 


\section{CONCLUSIONS}

Malathion at the rate of 1 pint of premiumgrade 57-percent malathion emulsifiable concentrate ( 0.63 pounds active ingredient) per 1,000 bushels gave good protection from insect damage, but not as good as that given by Cab-O-Sil or Kenite 2-I. The initial application did not change the test weight or the "No. 1" grade of the wheat. Twelve months later, the wheat was graded "No. 2." Malathion residues of 7.5 p.p.m. immediately after treatment degraded to 2.7 p.p.m. in 12 months. In bioassays, mortality of lesser grain borers was high for 6 months, but at 12 months it was no higher than in untreated wheat. Development of lesser grain borer progeny was prevented for 3 months and considerably suppressed for 12 months. Relatively few live lesser grain borers were found in samples probed from the malathiontreated wheat, and few emerged from the samples taken after 12 months. A small infestation of "wild" rice weevils had established itself in 12 months, and a few flat grain beetles were present, but no other insects.

Diazinon added to wheat at the rate of 0.5 pint of 48-percent diazinon emulsifiable concentrate ( 0.25 pound active ingredient) per 1,000 bushels did not give the desired protection against insects. Application of diazinon changed the grade of the wheat from "No. 1" to "Sample Grade, Distinctly Low Quality" due to the presence of an unknown substance. After 12 months the grade was "Sample-weevily." During the first 3 months, diazinon killed lesser grain borer adults in the grain but did not prevent development of their progeny. By the end of 12 months, considerable infestations of lesser grain borers and rice weevils had become established in the wheat. Although the damagé at 12 months was less in the diazinon-treated wheat than in the untreated wheat, it was twice that in malathion-treated wheat and 6 to 15 times that in dust-treated wheat.

Cab-O-Sil applied at the rate of 60 pounds per 1,000 bushels afforded excellent protection from insect damage to wheat for 12 months. The initial application reduced the test weight about 5.7 pounds per bushel and the grade from "No. 1 " to "Sample Grade,-Distinctly Low Quality" due to the presence of an unknown substance. Twelve months later the wheat was given the same grade. Although Cab-O-Sil did not cause complete mortality of lesser grain borer adults in bioassays, progeny development was greatly suppressed. Fewer insects were recovered throughout the 12 months, and fewer lesser grain borers emerged at the end of the test from the Cab-O-Sil-treated wheat than from wheat with any other treatment.

Kenite 2-I afforded excellent protection to the wheat, second only to the Cab-O-Sil treatment, in nearly all of the tests made during the 12 months. The application of 210 pounds per 1,000 bushels reduced the test weight of the wheat about 5 pounds per bushel and the grade from "No. 1 " to "No. 3-Said to Be Treated with Diatomaceous Earth." After 12 months, the wheat was graded "No, 4 -Said to Be Treated with Diatomaceous Earth." Kenite 2-I caused less mortality of lesser grain borers than malathion or diazinon for the first 3 months, but mortality continued at 80 to 95 percent for the remaining 9 months while mortalities from malathion and diazinon were fading to less than 20 percent. Only a few more insects were recovered from the Kenite 2-I-treated wheat than from the Cab-O-Sil-treated wheat. The Kenite 2-I protected the wheat from rice weevil and flat grain beetle infestations, but a relatively large number of lesser grain borers emerged from the samples taken at the end of the test.

\section{LITERATURE CITED}

1. Brown, A. W. A.

1963. INSECT RESISTANCE. PART I-NATURE AND PREVATENCE OF RESISTANCE. Farm Chem. 126 (10) : 21-24, 26, 28.

2. Cotton, R. T. and J. C. Frankenteid.

1949. SILICA AEROGELS FOR PROTECTING STORED SEED OR MILLED CEREAL PRODUCTS FROM INSECTS. J. Econ, Entomol. 42 (3) : 553.

3. DAvidson, W. A.

1963. GRADING AND CERTIFICATION OF GRAIN CONTAINING DIATOMACEOUS EARTH. GR Instruction 918-6 Aux. 1. Grain Div., Agr. Mktg.

4. KANE, JoYCE. Serv., U.S. Dept. Agr. 6 pp. + illus.

1967. SHICA-BASED DUSTS FOR THE CONTROL OF INSECTS INFESTING DRIFD SEA-FISH. J. Stored Prod. Res. 2 (3) : 251-255.
5. King, D. R., E. O. Morrison, and J. A. Stundmax.

1962. BIOASSAY OF CHEMICAL PROTECTANTS AND SURFACE TREATMENTS FOR THE CONTROL OF INSECTS IN STORED SORGHUM GRAIN. J. Econ. Entomol. 55 (4) : 506-510.

6. La Hue, Delmon W.

1965. EVALUATION OF MALATHION, SYNERGIZED PYRETHRUM, AND DIATOMACEOUS EARTH AS WHEAT PROTECTANTS .. IN SMALL BINS. U.S. Dept. Agr. Mktg. Res. Rept. 726, 13 pp., illus.

1966. EVALUATION OF MALATHION, SYNERGIZED PYRETHRUM, AND DIATOMACEOUS EARTH ON SHELLED CORN AS PROTECTANTS AGAINST INSECTS ... IN SMaLl BINS. U.S. Dept. Agr. Mktg. Res. Rept. 768, 10 pp. 
8.

1967. EVALUATION OF MALATHION, SYNERGIZED PYRETHRUM, AND A DIATOMACEOUS EARTH AS PROTECTANTS AGAINST INSECTS IN SORGHUM grain . . . in small bins. U.S. Dept. Agr. Mktg. Res. Rpt. 781, 11 pp.

9. - B. W. Clements, Jr., and Herbert Womack. 1959. IN-STORAGE TREATMENTS FOR THE PROTECTION OF FARMERS STOCK PEANUTS FROM INSECT DAMAFE-EXPLORATORY TESTS. U.S. Dept. Agr. Mktg. Res. Rpt. 363, 32 pp., illus.

10. - and C. C. Fifteld.

1967. EVALUATION OF FOUR INERT DUSTS ON WHEAT AS PROTECTANTS AGAINST INSECTS . . IN SMALL BINs. U.S. Dept. Agr. Mktg. Res. Rpt. 780, 24 pp., illus.

11. McDotgati, W. A.

1964. INSECTICIDES FAIL ON TWO PESTS. Queensland Agr. Jour. 90 (1) : 24.

12. Parkin, E. A.

1965. THE ONSET OF IN SECTICIDE RESISTANCE AMONG FIELD POPULATIONS OF STORED-PRODUCT INSects. J. Stored Prod. Res. 1 (1) : 3-8.

13. and R. Forster.

1962a. THE RICE WEEvIL AND LINDANe. Pest Infestation Res. H.M.S.O., London. pp. 37-38.
14.

1962b.

THE RUST-RED FLOUR BEETLE AND MALATHION. Pest Infestation Res. H.M.S.O., London. pp. 38-39.

15. Strong, R. G., and D. E. Sbur.

1963. PROTECTION OF WHEAT SEED WITH DIATOMACEOUS EARTH. J. Econ. Entomol. 56 (3) : $372-374$.

16. and

1964. INFLUENCE OF GRAIN MOISTURE AND STORAGE TEMPERATURE ON THE EFFECTIVENESS OF FIVE INSECTICIDES AS GRAIN PROTECTANTS. J. Econ. Entomol. 57 (1) : 44-47.

17. and

1965. INTERRELATION OF MOISTURE CONTENT, STORAGE TEMPERATURE, AND DOSAGE ON THE EFFECTIVENESS OF DIAZINON AS A GRAIN PROTECTANT AGAINST "SITOPHILUS ORYZAE"

18. (L.). J. Econ. Entomol. 58 (3) : 410-414. , - and G. J. PARTIDA.

1967. THE TOXICITY AND RESIDUAL EFFECTIVENESS OF MALATHION AND DIAZINON USED FOR PROTECTION OF STORED WHEAT. J. Econ. Entomol. 60 (2) : 500-505.

19. Telford, H. S., R. W. Zwick, Peter Sikonowski, and Margartet Weller.

1964. LABORATORY EVALUATION OF DIAZINON AS A WHEAT PROTECTANT. J. Econ. Entomol. 57 (2) : 272-275.

\section{APPENDIX}

\section{Characteristics of Inert Dusts}

1. Diatomaceous earth, Kenite 2-I :

Moisture _-..--_percent_-

Retained on 200-mesh screen _-_._-_percent_.

Retained on 325-mesh screen _......-percent__Silica $\left(\mathrm{SiO}_{2}\right)_{\text {-...-. do }}$ Surface area

sq. cm. per g--

Brightness -.- photovolt $\mathrm{pH}$ (approx.) _.......... Dry density

lb. per cu. $\mathrm{ft}_{-}$

2. Silica aerogel, Cab-O-Sil :

Free moisture $\left(105^{\circ}\right.$ C. $)$ percent

Apparent bulk density : Fluffy grade

lb. per cu. $\mathrm{ft}_{--}$

Densed grade_-_do_-_Bulking value gal. per 1b_-

Particle size range microns

Silica $\left(\mathrm{SiO}_{2}\right)_{--}$percent_-Surface area sq. meters per g--

pH _......

Color -

Refractive index

Specific gravity

\section{Grading of Grain Containing Foreign Substances}

8

Less than 3

Less than 10

88

30,000

70
7

Min. 14, Max. 15

0.2 to 1.5

2.5 to 3.5

6.5 to 7.0

0.057

0.015 to 0.020 99.0 to 99.7

175 to 200

3.5 to 4.0

White

1.55

2.1
Instructions for grading grain containing foreign substances are given in GR Instruction 918-6 Aux. 1 (3). Grain that contains an unknown foreign substance is graded "Sample Grade," except when the foreign substance is identified as a diatomaceous earth. An applicant for inspection of grain that contains or appears to contain diatomaceous earth may file a written application with the grain inspector for an examination to determine the presence of a diatomaceous earth. If the inspector determines that the grain contains no unknown foreign substance other than diatomaceous earth, he will grade the grain as though it contained no unknown foreign substance.

A thorough understanding of the grading instructions is needed before applying a diatomaceous earth to grain. Although diatomaceous earth is exempt from the requirement of a tolerance for residues on stored grain, an established tolerance of 8 p.p.m. of malathion is in effect. 